\title{
Surfaces
}

\section{Women's Studies Beside Itself}

Roundtable 1

\section{Elizabeth Weed}

Volume 7, 1997

\section{LE FÉMINISME HORS DE LUI-MÊME}

FEMINISM BESIDE ITSELF

URI : https://id.erudit.org/iderudit/1064804ar

DOI : https://doi.org/10.7202/1064804ar

Aller au sommaire du numéro

Éditeur(s)

Les Presses de l’Université de Montréal

ISSN

1188-2492 (imprimé)

1200-5320 (numérique)

Découvrir la revue

Citer cet article

Weed, E. (1997). Women's Studies Beside Itself: Roundtable 1. Surfaces, 7.

https://doi.org/10.7202/1064804ar d'utilisation que vous pouvez consulter en ligne.

https://apropos.erudit.org/fr/usagers/politique-dutilisation/ 


\section{Women's Studies Beside Itself Roundtable 1}

Elizabeth Weed

Brown University

Surfaces Vol. VII.105 (v.1.0A - 25/06/1997) - ISSN:

1188-2492

Copyright for texts published in Surfaces remains the property of authors. However, any further publication should be accompanied by an acknowledgement of Surfaces as the place of initial publication.

I want to thank the conference organizers for inviting me, for giving me a chance to read the volume and to think about Diane Elam and Robyn Wiegman's wonderful formulation of "feminism beside itself."

It wasn't until Naomi Schor pointed out to me that the last panel deals with feminist futures that I noticed that the future of women's studies for this panel is single, that the future of women's studies, a sub-category, depends on the multiple futures of academic feminism. One might argue the point because, of course, the future of women's studies is plural too, if for no other reason than that women's studies programs differ so greatly from institution to institution. One might also argue that since women's studies is by now driven by its own determining factors, both intellectual and institutional, the general future of academic feminism might be in some ways shaped by the more particular developments in women's studies. Indeed, it might be that it is in women's studies that feminism is most beside itself.

To explain what I mean by that, let me start by glossing the two categories. There is, first, feminism beside itselfthe question of the conference. On that topic I must say that although I am persuaded that today's feminism 
might be differently beside itself-in its self-reflexivity perhaps-it is hard to think of a time when it was not so. Feminism is, for starters, constitutively beside itself, constituted within the history of liberalism and the rights of Man in a set of inevitable contradictions somewhat misleadingly represented as the equality/difference conundrum. And then, depending on which history one embraces, there are the endless splits and struggles of early feminism between, for example, liberal feminism and socialist feminism, white feminism and black feminism, lesbian and straight, American and French, and so on. And all of these had their academic embodiments and their distinct theoretical debates.

As for women's studies, it is in its own way also constitutively beside itself. As Jane Gallop says in Reading Lacan,[ $\underline{\mathbf{1}}$ ] the ambiguity of the term women's studies is particularly suited to its topic. There is no knowing what the term "women's studies" claims as its own. Is it studies by women? studies about women? studies belonging to women? Rather than pin the term down, Gallop argues, why not retain it as curiously suggestive of the culture's historical positioning of the female as never quite subject, never quite object.

In the real world of institutions, of course, the ambiguities generated by women's studies are for the most part perfectly well managed. In spite of the occasional worry as to whether one needs to be a woman to participate in women's studies, or whether or not one needs to study women, in most institutions women's studies means something like "feminist-inflected studies of topics in some way related to women, gender, or sexual difference, taught and studied by women but also by men." Still, it can be instructive to look at what this management covers up-that is, what really happens when a feminism beside itself and a women's studies beside itself are brought together on the same institutional site.

We know that things have changed enormously from the early days when something called "women's studies" was the only place one could go to look for feminist courses. Today many of us are lucky enough to work in institutions where there are significant numbers of feminist courses offered across departments, and where women's studies is just one way among others of thinking about the production of feminist knowledge.

In her essay in Feminism Beside Itself, Susan Stanford Friedman comments that if Christina Hoff Sommers 
wanted to make a fair assessment of feminist scholarship she should have attended disciplinary conferences as well as the National Women's Studies Association. As one who attended many early NWSA conferences, though not the recently reformed ones, I can only concur. But the NWSA aside, one of the points Susan Friedman makes is that it is less easy to caricature disciplinary feminism than it is women's studies, a fact that has a lot to do with the formation of academic feminism in the US.

And yet, the ease with which some can attack women's studies also has something to do with women's studies itself. Certainly the rich development of feminist disciplinary knowledge does pose some questions for women's studies. On the one hand, we all know these disciplinary feminisms would not have been thinkable without the years of cross- and interdisciplinary work that women's studies in its various forms made possible. But in this period of well-developed disciplinary feminism, and well-developed discrete interdisciplinary feminism (such as the history/literature nexus), what can the role of women's studies be now? What propels women's studies intellectually, how does it organize its production of knowledge?

In an essay entitled "Discipline and Vanish,"[ $\underline{\mathbf{2}}$ ] Ellen Rooney warns cultural studies to be wary of consolidating a disciplinary object of study, and offers as an exemplary model what she calls the triple practice of women's studies, feminist theory, and the women's liberation movement. Following Rooney, one could argue that the strength of women's studies is that it has never allowed itself to be organized like an area studies; it cannot be contained by its object of study. Not only is "women's studies" ambiguous, but even if one were to take "women" as the field's object of study, "women" is an institutionally incoherent category which defies consolidation. Unlike almost all other fields, women's studies derives its coherence from-is inseparable from-its political-theoretical project, which is why, borrowing from Rooney's argument, it is so important to preserve women's studies in the academy.

However, if we are to heed the editors of Feminism Beside Itself, feminism can no longer be seen as $a$ project, or better, today's political-theoretical consensus is that there is no consensus. If that is indeed the case, what can the institutional role of women's studies be? 
I want to make two suggestions as to how one might think about women's studies today. Both have to do with women's studies' relationship to the political-theoretical. First, I think we need to be much clearer about the ways women's studies is constituted. Everywhere in the academy feminists are calling for more specificity, except, it seems, in considerations about the very underpinnings of what we call women's studies. There, a kind of vague pluralism often stands in for theoreticalpolitical specificity. This is not surprising. When it comes to the practical work of developing courses and curricula, what do interdisciplinary faculty groups have, after all, to ground their work? They usually lack a shared, refined disciplinary context-the context which allows today's feminist disciplinary scholars to pose nuanced and challenging questions. And they lack, as we know, a self-evident object of study. In lieu of these, what often happens is that a kind of generalized thematics provides the framework for interdisciplinary or multidisciplinary courses. Problems like rape or domestic violence or reproductive rights or the gender-race-class nexus are used as organizing tools. The problem is, of course, that once these rubrics are in place it is very difficult to denaturalize the terms. How to get students to think about the historical production of the discourses of rape, of the historical vicissitudes of the framing of domestic violence, or violence in general when the very terms of the course seem to reinforce the notion of a received reality?

One way of solving the problem faced by women's studies faculty groups is to recognize that merely to assert that we have multiple feminist projects gets us nowhere unless we situate those projects in their various discursive contexts. A postmodern feminist theorist who sees a certain fragmentation as salutary in cultural politics will likely have real disagreements with the feminist scholar who believes that a global economic system requires a generalized theorization and critique of that system. A neo-pragmatist feminist critic will have strong disagreements with a post-structuralist. And so on. These are productive disagreements that should be pursued and made more visible both within women's studies faculty groups and in women's studies curricula. In that way the arguments within a broadly construed academic feminism might seem less circular, less selfreflexive. Without such contextualization we seem destined to return again and again to debates about disembodied and abstracted concepts such as agency, referentiality, and materiality. Such debates can only be frustrating and enervating. 
If my first suggestion is that we connect women's studies work more closely to its theoretical-political contexts, that we make women's studies more explicitly political in a sense, my second is that we make it less so. This is only an apparent paradox because what is at stake is our understanding of the different meanings of the word "political," of the differences between the political nature of women's studies scholarship and all other forms of politics. All politics are not homologous, but at a time when, as Barbara Ehrenreich has said, the number of Americans who consider themselves on the "left" is probably smaller than the number who have had contact with extra-terrestrial beings, the temptation to judge intellectual work by the crucible of current political movements is great.

One example of the erasure of the specificity of intellectual work is the way the historical shifts in feminist theory have been construed. Most histories of academic feminism report that the analytical category "Woman" was displaced by "women," and a good thing too. I would argue that the category of Woman, as produced by poststructuralist and psychoanalytic theorists of the 70's and early 80's, was not a mistake to be corrected and replaced by theories of the differences among women. It was, rather, an historically produced theory which, like all theories, yielded insights and blind spots. This is by no means to minimize blind spots, nor to forget the racism of institutional power relations. It is to say, rather, that to judge the current usefulness of the theoretical category of Woman one needs to reread earlier and later theories with and against one another. Theoretical insights are produced through rereadings and displacements. To reduce the poststructuralistpsychoanalytic "Woman" and the variously theorized "women" to a simple narrative of political displacement mirroring the social field is to take neither seriously as a theoretical category. It is to collapse into an indistinguishable blur the theoretical, the descriptive, and the prescriptive.

Both of these moves-the contextualizing of politicaltheoretical feminist debates and the attention to the specificity of feminist intellectual production-are more likely to occur in a systematic way in the interdisciplinary context of women's studies than within individual disciplines. If this happens, disciplinary feminism can only benefit. 
NOTES

1. Jane Gallop, Reading Lacan (Ithaca: Cornell University Press, 1985).

2. Ellen Rooney, "Discipline and Vanish: Feminism, the Resistance to Theory, and the Politics of Cultural Studies," differences 2 no 3 (1990), pp. 14-28.

Accueil Surfaces | Table des matières | Recherche Surfaces Home Page | Table of Contents | Search

PUM | Livres | Revues | Publications électroniques |

Vente et distribution 